\title{
Evaluation of Online Classes Using the Seven Principles of Effective Teaching
}

\author{
Cynthia A. Faulkner, Ph.D., MSW, LCSW-S \\ Samuel S. Faulkner, Ph.D., MSSW, LCSW \\ Texas A\&M University - Kingsville \\ 910 West Santa Gertrudis Avenue \\ Kingsville, Texas 78363, USA
}

\author{
Cynthia A. Faulkner, Ph.D., MSW, LCSW-S \\ Marcie M. Cutsinger, Ed.D., MSW, LCSW \\ David S. King, MA., MSW, LMSW \\ Shanel M. Bishop, DSW, LMSW \\ James Long, Jr., Th.D., LCSW \\ Indiana Wesleyan University \\ 1900 West 50th Street \\ Marion, Indiana 46953, USA
}

\begin{abstract}
This article uses the seven principles of effective teaching to measure student's satisfaction with an online course. A total of two-hundred and forty-four students at a regional university participated in online elective courses. The instructor employed the seven principles for effective teaching to measure students' satisfaction with the course. Students reported high satisfaction with the course, with the instructor's methods of information delivery and clear expectations of the course.
\end{abstract}

Keywords: Online teaching, seven principles of effective teaching

\section{Introduction}

In an age of increasing demand for accountability, the academy has not escaped the call for professors to be more rigorous in their course delivery - especially as it relates to course outcomes and student's evaluation of their experience in the class. In the past decade, as the economy has experienced a definite slow-down and a shrinking middle class, today's universities have felt the impact of the economic decline. Today, colleges and universities across the nation are scrambling to provide services, classes, and instruction to students with shrinking resources. In the midst of these challenges, professors are tasked with the onerous job of trying to provide quality educational experiences, with less resource, to accomplish the job.

At the same time, students find themselves in the unenviable position of trying to balance the demands of jobs, families, and class work - all at the same time. Hillman (2005) finds that today's university students are finding it more and more difficult to juggle work and study. Increasingly, students find themselves constricted by place, work, and other demands - making it harder for them to attend classes in a traditional setting. Verschelden (2017) described this as a decreased 'mental bandwidth' where students are unable to pay attention effectively in school due to competing life demands that take precedence over one's cognitive ability to focus solely on school. Not surprisingly, many students are turning to the internet to solve this dilemma. At one time, in the not too distant past, before the invention of the internet, taking classes via correspondence study was considered with suspicion, at best. Today, classes taken by distance education are part of the mainstream of modern education. The United States Department of Education National Center for Educational Statistics reports that in the Fall of 2015, almost 6 million $(5,954,121)$ students were enrolled in an online course. 
This article is the summation of an attempt to measure the impact of classes taken via the internet. Specifically, to employ Chickering and Gamson's (1987) "Seven Principles for Good Practice in Undergraduate Education" to evaluate online social work courses. The seven principles are:

1. Encourages contact between student and faculty;

2. Develops reciprocity and cooperation among students;

3. Encourages active learning;

4. Gives prompt feedback;

5. Emphasizes time on task;

6. Communicates high expectations; and

7. Respects diverse talents and ways of learning.

The seven principles are well documented and utilized in education. Other authors, (Goldberg, Clement \& Cotter 2011;Hadsell, 2005; Shieh, Gummer, \& Niess, 2008) have relied on these seven principles to evaluate the outcome of their programs. The researchers in this study developed an evaluation tool based upon the seven principles and then used this tool to measure the effectiveness of these classes. Using both qualitative and quantitative methods, the authors' collected data from over two years of classes using the evaluation tool. The following is a summation of their research and their findings.

\section{Literature Review}

Technology in the academy is changing rapidly. Nowhere is this more evident than in the area of online teaching. Almost 70 percent of college administrators believe that online learning will be a significant element of a college's success (Allen \& Seaman, 2013). As recently as a decade ago, Chen (2007) stated that "over the past two decades, instructional design principles and practices have shifted from objectivism to constructivism" (p.73). This shift away from a logical positivist approach to a more post-modernist approach implies a difference in methods of delivery. For centuries, classroom instruction has been organized around an objectivist approach whereby instructors organize goals and objectives, establish learning outcomes, and deliver information. Afterwards, students are measured on their performance, and effectiveness and success of the model is based on these outcomes.

However, with a shift in delivery of information away from strictly face-to-face instruction to online learning - a need exists to re-examine preconceived notions of what it means to be a learner. Constructivism challenges the old notions of information delivery and introduces new ideas. Just as Malcolm Knowles believed that adults needed a reason to learn (based on the relevance to their job or their life) (Knowles, 1983), constructivism is based on the notion that "knowledge is individually constructed and socially reconstructed by learners based on their interpretations of experiences in the world" (Jonassen, 1999, p. 217). Essentially, instructors need to reconsider the old paradigm of how knowledge is transferred in light of emerging technology and student expectations. Baran, Correia, and Thompson (2013) echo this sentiment in their research stating that it is imperative to understand how successful online teachers transfer their knowledge to students.

Today's students were raised with technology and are comfortable as consumers and participants in an increasingly complex world. In that regard, the concept of "teacher" is evolving - especially for virtual or online courses. Today's teachers are viewed more as facilitators, guides, "information designers" and mentors than individuals who serve as experts in their individual field and expositors of knowledge who stand in front of a classroom and convey knowledge through lecture. The online classroom is much more focused on learning that employs the solving of real world problems. Today's student expects to be actively engaged in the learning process - not a passive recipient of information (Baran et al., 2013).

With this shift in focus new challenges arise in measuring success. Questions that surface include: "Are students truly learning?" and "Is the information that students learn useful in helping them to be better prepared to function in society, or to be better equipped to solve new and emerging problems?"These are large and difficult questions to answer and may not be known until significant time has passed. What is for certain, however, is that online learning is a fact of today's world and will be for the foreseeable future. As part of the new reality, we as educators need tools for evaluating the effectiveness of our teaching methods.

Cable and Cheung (2017) raise similar concerns as those identified above. They seek to answer the questions: "How can we develop high quality online courses?" "How can we know whether our online teaching is effective?" (Cable \& Cheung, 2017, p.1). 
The authors utilize the Seven Principles for Good Practice in Undergraduate Education (Chickering \& Gamson, 1987) and apply them to a graduate level course. They found these principles to be appropriate and effective tools for evaluating online courses (even though they were originally developed to be used in traditional classrooms utilizing face-to-face teaching methods).

Lopez-Diaz, Ronquillo-Chavez, Madero-Villanueva, Robledo-Portillo, and Dena-Hernandez (2018) seek to answer the same question from the learner's perspective: asking the student to evaluate the effectiveness of the instructor and the overall course. The authors developed a 13-item questionnaire to measure student's satisfaction with a course and effectiveness of teaching methods. The results indicate that their survey instrument is both effective and reliable as a measure for determining effectiveness of online teaching (Lopez-Diaz, et al., 2018).

At least one study, by Weber, Hillmert and Rott (2018) raises the issue that students, while comfortable with technology, may not always be skilled at finding and evaluating information online. It is important, they assert, to ensure that students have the necessary skills to research, find, and evaluate information (Weber et al, 2018). It is important to keep in mind that students may lack critical skills needed to locate, evaluate, and assess information. Part of teaching online, for the instructor, means that students have all of the skills necessary to be successful in the course. Because the academy is tasked with evaluating our methods of information delivery, and because online teaching has become an integral part of the way classes are delivered, it is important to measure the effectiveness of online classes on an ongoing basis. This article is a small piece of the continuing effort to measure the success of online teaching.

\section{Methodology}

The goal of this study was to apply the seven principles for good practice in undergraduate education to online classes. The research question was, "Can the seven principles for good practice in undergraduate education be used to measure online courses?" The researchers, for the purpose of this study, identified the following independent variables: gender, age, major area of study, classification (freshman - senior), hours per week the student worked on the class, number of times per week the student logged onto the class, participation, investment, and reason for taking the online course. Demographic variables included: gender, age, major, and classification. The dependent variable was a 17-item evaluation tool based on the seven principles and a qualitative section that asked subjective questions about the student's involvement and participation levels. The 17-item survey asked students to respond using the following rating scale:

$1=$ Strongly Agree

$2=$ Agree

$3=$ Neither Agree nor Disagree

$4=$ Disagree

$5=$ Strongly Disagree

The items on the scale asked the following questions:

1. The instructor gave prompt information to the class throughout the course.

2. The instructor was clear about when to expect responses from the emails.

3. The instructor provided opportunities for the students to learn from each other.

4. The instructor encouraged discussion.

5. The instructor encouraged critical thinking (the ability to analyze facts, generate and organize ideas, and defend opinions).

6. The instructor encouraged creative thinking in discussion and assignments.

7. The discussions had a clear topic area.

8. The instructor gave feedback on assignments in a timely manner.

9. The instructor provided feedback on discussions.

10. Assignments and quizzes are regularly scheduled with clear deadlines.

11. The instructor stated the learning objectives in the syllabus and assignments.

12. The instructor selected relevant readings, quizzes and assignments that challenged me.

13. The instructor provided clear expectations for discussion board postings.

14. The instructor provided instructions for assignments.

15. The instructor was interested in diverse viewpoints.

16. The instructor allowed students to select own sub-topics within assignments. 
17. The instructor allowed students to select own sub-topics within discussions.

The researchers utilized a convenience sample and collected data over the course of two years from ten different classes. These classes ranged from a variety of disciplines including: social work, sociology, and women's studies. A total of 244 students participated in the study $(n=244)$. Students' majors varied widely, including: social work, sociology, criminology, university studies, and a generic category - other. Three separate instructors participated in the study, all agreeing to use the specified evaluation tools to measure student outcomes at the end of the course. The following are the results of this study.

\section{Results}

\section{Descriptive Statistics}

An analysis of the data was conducted using the Statistical Package for Social Sciences (SPSS). The researchers found the following results. The demographic variable, gender, revealed that of the 244 students participating (n =244), 219 were female and 25 were male (see Table One below).

\begin{tabular}{ll}
\multicolumn{2}{c}{ Table 1Participant Gender } \\
\hline Females & 219 \\
Males & 25 \\
$\mathrm{~N}$ & 244 \\
\hline
\end{tabular}

When a descriptive statistic for age was conducted, the ages ranged from 17 years old to 52 years old with the mean age of 29 years (see Table Two below).

Table 2 Participant Age

\begin{tabular}{lll}
\hline Range & Youngest & Oldest \\
& 17 & 52 \\
Mean Age & & 29 \\
\hline
\end{tabular}

When a descriptive analysis of student's major was conducted, the majority of students had declared social work as their major $(\mathrm{n}=105)$ (see Table Three below).

Table 3 Participants Declared Major

\begin{tabular}{lll}
\hline Major & Frequency & Percent \\
\hline Social Work & 105 & 43.0 \\
Sociology & 13 & 5.3 \\
University Studies & 51 & 20.9 \\
Criminology & 6 & 2.5 \\
Other & 69 & 283 \\
\hline Total & 244 & 100
\end{tabular}

The majority of the students who participated in these classes were seniors $(n=183)$ followed by juniors $(n=42)$ (see below).

Table Four Classification

\begin{tabular}{lll}
\hline Class & Frequency & Percent \\
\hline Senior & 183 & 75.0 \\
Junior & 42 & 17.2 \\
Sophomore & 17 & 7.0 \\
Freshman & 2 & .8 \\
Total & 244 & 100.0 \\
\hline
\end{tabular}

In order to measure one of the principles (number five: emphasizes time on task), the authors measured the number of hours per week each student self-reported working on this course. The majority was 1-4 hours (reported by 67 students) with the second most frequently occurring being $5-8$ hours (reported by 65 students) (see Table Five below). The researchers also asked the number of times the student logged in to the course per week. The most frequently occurring was $5-8$ times per week $(n=101)$ with $1-4$ times being the second most frequently occurring $(\mathrm{n}=52)$ (see Table Six below). 
Table Five Hours per Week on Course

\begin{tabular}{lll}
\hline Hours & Frequency & Percent \\
\hline Unanswered & 2 & .8 \\
$1-4$ hours & 67 & 27.5 \\
$5-8$ hours & 65 & 26.6 \\
$9-12$ hours & 61 & 25.0 \\
$13-16$ hours & 26 & 10.7 \\
$17-20$ hours & 8 & 3.3 \\
Over 20 hours & 14 & 5.7 \\
Missing & 1 & .4 \\
Total & 244 & 100.0 \\
\hline
\end{tabular}

\begin{tabular}{|c|c|c|}
\hline Total & 244 & 100.0 \\
\hline \multicolumn{3}{|c|}{ Table Six Number of Times Logged in per Week } \\
\hline Logged & Frequency & Percent \\
\hline $1-4$ & 52 & 21.3 \\
\hline $5-8$ & 101 & 41.4 \\
\hline $9-12$ & 37 & 15.2 \\
\hline $13-16$ & 20 & 8.2 \\
\hline $17-20$ & 16 & 6.6 \\
\hline Over 20 & 15 & 6.1 \\
\hline Unanswered & 3 & 1.2 \\
\hline Total & 244 & 100.0 \\
\hline
\end{tabular}

Students were also asked to rate their overall participation in the course. Participation level was rated on a nominal level (I actively participated - true or false). A total of 235 students or 96.3 percent indicated they actively participated (see Table Seven below).

Table Seven Participation

\begin{tabular}{lll}
\hline I actively participated in this course & Frequency & Percent \\
\hline True & 235 & 96.3 \\
False & 9 & 3.7 \\
Total & 244 & 100.0 \\
\hline
\end{tabular}

Another of the seven principles that was measured was number five (emphasizes time on task). Students were asked to rate their amount of investment in the class. The overwhelming majority (235 of the 244 students) reported that it was true; they had invested enough time and energy to meet or exceed requirements (see Table Eight below).

Table Eight Investment

\begin{tabular}{lll}
\hline $\begin{array}{l}\text { I invested enough time and energy into this course to meet or } \\
\text { exceed requirements }\end{array}$ & Frequency & Percent \\
\hline True & 235 & 96.3 \\
False & 9 & 3.7 \\
Total & 244 & 100.0 \\
\hline
\end{tabular}

Instructors also asked students to rate the reasons for taking the course as an online course (as opposed to face-toface). The most frequently occurring response was "convenience" $(\mathrm{n}=146)$ (see Table Nine below).

Table Nine Reason Student Took This Course

\begin{tabular}{lll}
\hline Convenience & Bound by Time & Bound by Place \\
\hline $60 \%$ & $39 \%$ & $20 \%$ \\
$\mathrm{~N}=146$ & $\mathrm{~N}=95$ & $\mathrm{~N}=48$ \\
\hline
\end{tabular}

\section{Inferential Statistics}

As mentioned previously, the instructors created an instrument to measure their teaching effectiveness (utilizing the seven principles for effective teaching). This 17-item instrument measured such things as to: how prompt the instructor was to provide information throughout the class, the instructor providing opportunities for students to learn from each other, and the instructor's encouraging of discussion. 
The authors conducted a Cronbach's Alpha to determine the reliability of the scale they were using for the dependent variable. When the Cronbach's Alpha was conducted, the overall score was .964 (Standardized Item Alpha - .969) ( $\mathrm{F}=38.734 ; \mathrm{p}<.000)$ (see Table Ten below).

Table Ten Reliability Analysis (Scale - Alpha)

\begin{tabular}{|l|l|l|l|}
\hline Item & Mean & Standard Deviation & Item if Alpha Deleted \\
\hline 1 & 1.19 & .513 & .963 \\
\hline 2 & 1.40 & .538 & .962 \\
\hline 3 & 1.30 & .493 & .961 \\
\hline 4 & 1.32 & .550 & .961 \\
\hline 5 & 1.53 & .722 & .963 \\
\hline 6 & 1.48 & .745 & .963 \\
\hline 7 & 1.40 & .617 & .960 \\
\hline 8 & 1.26 & .502 & .962 \\
\hline 9 & 1.46 & .699 & .961 \\
\hline 10 & 1.26 & .475 & .962 \\
\hline 11 & 1.38 & .620 & .961 \\
\hline 12 & 10.20 & 28.019 & .961 \\
\hline 13 & 1.41 & .631 & .961 \\
\hline 14 & 1.17 & .406 & .963 \\
\hline 15 & 1.21 & .475 & .963 \\
\hline 16 & 1.65 & .825 & .961 \\
\hline 17 & 1.78 & .937 & .965 \\
\hline
\end{tabular}

Notes: $\mathrm{ALPHA}=.964$ Standardized item alpha $=.969$ F-score: 38.734 Sig: .000

Students were asked to react to each of the principles (utilizing the survey questions provided).

\section{Principle One: Encourages contact between students and faculty.}

When asked to respond to question number one (the instructor gave prompt information to the class throughout the course), students either strongly agreed $(75.4 \%)$ or agreed $(21.7 \%)$ (see Table Eleven below).

Table Eleven

The Instructor Gave Prompt Information Throughout the Course

\begin{tabular}{lll}
\hline Scale Item & Frequency & Percent \\
\hline Strongly Agree & 184 & 75.4 \\
Agree & 53 & 21.7 \\
Undecided & 6 & 2.7 \\
Disagree & 0 & 0 \\
Strongly Disagree & 0 & 0 \\
Unanswered & 1 & .4 \\
Total & 244 & 100.0 \\
\hline
\end{tabular}

The second question (the instructor was clear about when to expect responses from emails) also showed favorable responses from students. A majority $(\mathrm{n}=161)$ of the students strongly agreed (see Table Twelve below).

Table Twelve the Instructor Was Clear About When to Expect Responses from Emails

\begin{tabular}{lll}
\hline Scale Item & Frequency & Percent \\
\hline Strongly Agree & 161 & 66.0 \\
Agree & 70 & 28.7 \\
Undecided & 10 & 4.1 \\
Disagree & 3 & 1.2 \\
Strongly Disagree & 0 & 0 \\
Unanswered & 0 & 0 \\
Total & 244 & 100.0 \\
\hline
\end{tabular}




\section{Principle Two: Develops reciprocity and cooperation among students}

Two questions were asked to measure this principle. The first question: the instructor provided opportunities for the students to learn from each other yielded the following responses: the majority $(n=143)$ responded that they strongly agreed (see Table Thirteen below).

Table Thirteen the Instructor Provided Opportunities for the Students to Learn From Each Other

\begin{tabular}{lll}
\hline Scale Item & Frequency & Percent \\
\hline Strongly Agree & 143 & 58.6 \\
Agree & 76 & 31.1 \\
Undecided & 21 & 8.6 \\
Disagree & 4 & 1.6 \\
Strongly Disagree & 0 & 0 \\
Unanswered & 0 & 0 \\
Total & 244 & 100.0 \\
\hline
\end{tabular}

The second question in principle two which was, the instructor encouraged discussion, received similar results (159 students strongly agreed) (see Table Fourteen below).

\begin{tabular}{lll}
\multicolumn{3}{c}{ Table Fourteen The Instructor Encouraged Discussion } \\
\hline Scale Item & Frequency & Percent \\
\hline Strongly Agree & 159 & 65.2 \\
Agree & 60 & 24.6 \\
Undecided & 19 & 7.8 \\
Disagree & 6 & 2.5 \\
Strongly Disagree & 0 & 0 \\
Unanswered & 0 & 0 \\
Total & 244 & 100.0 \\
\hline
\end{tabular}

\section{Principle Three: Encourages active learning}

Three questions measured this principle. The first question, the instructor encouraged critical thinking (the ability to analyze facts, generate and organize ideas, and defend opinions), produced the following results: 175 students (71.7\%) stated that they strongly agreed (see Table Fifteen below).

Table Fifteen the Instructor Encouraged Critical Thinking

\begin{tabular}{lll}
\hline Scale Item & Frequency & Percent \\
\hline Strongly Agree & 175 & 71.7 \\
Agree & 65 & 26.6 \\
Undecided & 4 & 1.6 \\
Disagree & 0 & 0 \\
Strongly Disagree & 0 & 0 \\
Unanswered & 0 & 0 \\
Total & 244 & 100.0 \\
\hline
\end{tabular}

The second question in principle three, the instructor encouraged creative thinking, had similar results. Seventyone percent $(n=174)$ of the students stated that they strongly agreed with this statement (see Table Sixteen below).

Table Sixteen Creative Thinking

\begin{tabular}{lll}
\hline Scale Item & Frequency & Percent \\
\hline Strongly Agree & 174 & 71.3 \\
Agree & 62 & 25.4 \\
Undecided & 7 & 2.9 \\
Disagree & 1 & .4 \\
Strongly Disagree & 0 & 0 \\
Unanswered & 0 & 0 \\
Total & 244 & 100.0 \\
\hline
\end{tabular}


The third question in principle three, the discussions had a clear topic area, showed results very much like the others in this principle. The majority of the students (208) reported that they either agreed or strongly agreed with this statement (see Table Seventeen below).

Table Seventeen the Discussion Had a Clear Topic Area

\begin{tabular}{lll}
\hline Scale Item & Frequency & Percent \\
\hline Strongly Agree & 148 & 60.7 \\
Agree & 60 & 24.6 \\
Undecided & 14 & 5.7 \\
Disagree & 0 & 0 \\
Strongly Disagree & 0 & 0 \\
Unanswered & 22 & 9.0 \\
Total & 244 & 100.0 \\
\hline
\end{tabular}

\section{Principle Four: Gives prompt feedback}

There were two questions relating to principle four. The first question, the instructor gave feedback on assignments in a timely manner also showed that students viewed this very positively. Slightly over seventy-five percent of the students (75.8\%) stated that they strongly agreed with this statement (see Table Eighteen below).

Table Eighteen the Instructor Gave Feedback on Assignments in a Timely Manner

\begin{tabular}{lll}
\hline Scale Item & Frequency & Percent \\
\hline Strongly Agree & 185 & 75.8 \\
Agree & 55 & 22.5 \\
Undecided & 4 & 1.6 \\
Disagree & 0 & 0 \\
Strongly Disagree & 0 & 0 \\
Unanswered & 0 & 0 \\
Total & 244 & 100.0 \\
\hline
\end{tabular}

The second question in principle four was, instructor provided feedback on discussions. Students reported that they strongly agreed with this statement (63.9\%) or agreed (27.5\%) (see Table Nineteen below).

Table Nineteen

The Instructor Provided Feedback on Discussions

\begin{tabular}{lll}
\hline Scale Item & Frequency & Percent \\
\hline Strongly Agree & 156 & 63.9 \\
Agree & 67 & 27.5 \\
Undecided & 17 & 7.0 \\
Disagree & 4 & 1.6 \\
Strongly Disagree & 0 & 0 \\
Unanswered & 0 & 0 \\
Total & 244 & 100.0 \\
\hline
\end{tabular}

\section{Principle Five: Emphasizes time on task}

Principle five had one question, assignments and quizzes are regularly scheduled with clear deadlines. The students' responses indicated they were well satisfied with this (84.4\% stated they strongly agreed) (see Table Twenty below).

Table Twenty Assignments and Quizzes are Regularly Scheduled with Clear Deadlines

\begin{tabular}{lll}
\hline Scale Item & Frequency & Percent \\
\hline Strongly & 206 & 84.4 \\
Agree & & \\
Agree & 35 & 14.3 \\
Undecided & 3 & 1.2 \\
Disagree & 0 & 0 \\
Strongly & 0 & 0 \\
Disagree & & \\
Unanswered & 0 & 0 \\
Total & 244 & 100.0 \\
\hline
\end{tabular}




\section{Principle Six: Communicates high expectations}

Four questions measured principle six. The first question asked about the extent that the instructor stated the learning objectives in the syllabus and assignments. Almost $99 \%(\mathrm{n}=98.8 \%)$ stated that they agreed or strongly agreed with this statement (see Table Twenty-one below).

Table Twenty-One the Instructor Stated the Learning Objectives in the Syllabus and Assignments

\begin{tabular}{lll}
\hline Scale Item & Frequency & Percent \\
\hline Strongly Agree & 204 & 83.6 \\
Agree & 37 & 15.2 \\
Undecided & 1 & .4 \\
Disagree & 0 & 0 \\
Strongly Disagree & 2 & .8 \\
Unanswered & 0 & 0 \\
Total & 244 & 100.0 \\
\hline
\end{tabular}

The second question in principle six, the instructor selected relevant readings, quizzes, and assignments that challenged me were also positive. Sixty-two percent of the students stated that they strongly agreed (see Table Twenty-two below).

Table Twenty-Two the Instructor Selected Relevant Readings, Quizzes, and Assignments That Challenged Me

\begin{tabular}{lll}
\hline Scale Item & Frequency & Percent \\
\hline Strongly Agree & 153 & 62.7 \\
Agree & 85 & 34.8 \\
Undecided & 6 & 2.5 \\
Disagree & 0 & 0 \\
Strongly Disagree & 0 & 0 \\
Unanswered & 0 & 0 \\
Total & 244 & 100.0 \\
\hline
\end{tabular}

The third question, the instructor provided clear expectations for discussion board postings, indicated that students were also favorably disposed. Most of the students $(n=229)$ reported they either agreed or strongly agreed (see Table Twenty-three below).

Table Twenty-Three the Instructor Provided Clear Expectations for Discussion Board Postings

\begin{tabular}{lll}
\hline Scale Item & Frequency & Percent \\
\hline Strongly Agree & 169 & 69.3 \\
Agree & 59 & 24.2 \\
Undecided & 15 & 6.1 \\
Disagree & 1 & .4 \\
Strongly & 0 & 0 \\
Disagree & & \\
Unanswered & 0 & 0 \\
Total & 244 & 100.0 \\
\hline
\end{tabular}

The last question in principle six asked about the instructor posting instructions for assignments. Students agreed or agreed strongly $(n=241)$ that the instructor provided instruction for their assignments (see Table Twenty-four below).

Table Twenty-Four the Instructor Provided Instructions for Assignments

\begin{tabular}{lll}
\hline Scale Item & Frequency & Percent \\
\hline Strongly Agree & 197 & 80.8 \\
Agree & 44 & 18.0 \\
Undecided & 1 & .4 \\
Disagree & 2 & .8 \\
Strongly Disagree & 0 & 0 \\
Unanswered & 0 & 0 \\
Total & 244 & 100.0 \\
\hline
\end{tabular}




\section{Principle Seven: Respects diverse talents and ways of learning}

Three questions measured principle seven. The first question, the instructor was interested in diverse viewpoints, showed that 163 of the 244 students (66.9\%) strongly agreed (see Table Twenty-five below).

Table Twenty-Five The Instructor was Interested in Diverse Viewpoints

\begin{tabular}{lll}
\hline Scale Item & Frequency & Percent \\
\hline Strongly Agree & 163 & 66.9 \\
Agree & 66 & 27.0 \\
Undecided & 14 & 5.7 \\
Disagree & 1 & .4 \\
Strongly Disagree & 0 & 0 \\
Unanswered & 0 & 0 \\
Total & 244 & 100.0 \\
\hline
\end{tabular}

The second question was meant to measure principle number seven. It asked about instructors allowing students to select their own sub-topics within assignments. Over half of the students either agreed or strongly agreed $(\mathrm{n}=$ 184) (see Table Twenty-six below).

Table Twenty-Six the Instructor Allowed Students to Select Their Own Sub-topics within Assignments

\begin{tabular}{lll}
\hline Scale Item & Frequency & Percent \\
\hline Strongly Agree & 124 & 55.0 \\
Agree & 62 & 27.9 \\
Undecided & 32 & 14.4 \\
Disagree & 6 & 2.7 \\
Strongly Disagree & 0 & 0 \\
Unanswered & 0 & 0 \\
Total & 224 & 100.0 \\
\hline
\end{tabular}

The last question allowed students to select own sub-topics within discussions, a total of 172 students responded that they either agreed or strongly agreed (see Table Twenty-seven below).

Table Twenty-Seven the Instructor Allowed Students to Select Own Sub-topics Within Discussions

\begin{tabular}{lll}
\hline Scale Item & Frequency & Percent \\
\hline Strongly Agree & 110 & 49.5 \\
Agree & 62 & 27.9 \\
Undecided & 35 & 15.8 \\
Disagree & 14 & 6.3 \\
Strongly Disagree & 0 & 0 \\
Unanswered & 1 & 0 \\
Total & 222 & 100.0 \\
\hline
\end{tabular}

In addition, there were qualitative responses. Some of the responses from the students were:

\section{Student-Faculty Contact:}

"I found this course very interesting and was thankful the instructor was easy to contact. She was also easy to communicate with and answered e-mails with quick responses." "I appreciate your organization, availability, and prompt feedback on all assignments and emails."

"I always feel that Dr. Faulkner is an excellent professor and very nice and always willing to help as needed just to call or stop by." "I was very pleased with the quick response when I emailed the instructor."

\section{Encourages Active Learning:}

"I liked being able to see everyone's response. Sometimes in a regular classroom you only hear what a couple of people think, this way you can see everyone's thought and ideas." "I liked doing the readings and discussion boards. I feel like I learned a lot from reading other peoples' responses as well." "She has included scenarios that have made students read related chapter and broadened their minds." "I find this topic very interesting and learned as much from other responses as my own ideas. We all have a different way of approaching the same topic." 


\section{Time on Task:}

"I like how you had the assignments posted ahead of the due date, this allowed us who work full time to complete the assignments as time allowed and still have them finished by the deadline."

"I thought the instructor clearly stated all assignments and gave an acceptable amount time to complete assignments."

"The objectives were very clear which allowed me to better manage my time so I could get my assignments finished when assigned."

"Assignments were spaced far enough apart that those with busy schedules could easy work around."

\section{Respects Diverse Talents and Ways of Learning}

"I enjoyed this class and learned so much from the weekly readings."

"I thought the websites you listed were great!"

"The allowance you made for students to concentrate their assignments on the individual subtopics of their choice made the class very interesting and enjoyable." "She made it very interesting by letting us include our own life examples into the assignments."

\section{Discussion}

Several issues emerged as a result of this study. As with any study, there were both positive and negative outcomes. We will address the positive outcomes first. While online instruction is gaining in popularity, and it is not likely to go away any time soon, it is important for faculty and institutions, alike, to adapt to this method of course delivery if institutions want to remain competitive in today's market. The positive outcomes were that the course encouraged communication between the student and the instructor; and the student and other members of the class. Part of the feedback for the class noted that students liked the discussion boards because it forced participation as opposed to face-to-face classes where students only heard from a select few in the classroom.

The second positive outcome was that students responded positively to having clear deadlines and having clear expectations about the course. Not only did this present clear guidelines for what the instructor expected from students, but it had the added benefit of allowing students to work ahead if they so choose.

Another consistent theme from student's feedback was the fact that the instructor was both helpful and responsive - answering emails and questions in a thorough and timely manner. This contributed to students having a positive experience in the course. This responsiveness, however, carries with it both positive and negative aspects. The positive is that if an instructor is diligent and responds in a timely manner, students feel validated and valued.

If, however, instructors are lax in their response times, the opposite effect occurs. Students tend to have a more negative experience in the course, they feel a sense that the instructor is not as invested (regardless of whether this is true or not), and the potential exists for students to not take the course seriously.

One other negative aspect of online learning is an inherent flaw in the system. Distance education, in general, and classes delivered via the internet, in particular, assumes several things. They assume that students are motivated, self-directed and capable of working independently. Secondly, it assumes that the learner is capable of evaluating information and critically analyzing what is being presented to make self-determination as to what is valid information. These are some large assumptions that can lead to erroneous information and dire consequences.

As final a discussion item regarding the data presented above, the exploratory nature of this study should be noted. Although the data is valuable in identifying the positive responses by students to efforts made by faculty to align with the 7 principles of good practice, as an initial study relying on a convenience sample, additional research is needed to contribute the knowledge base.

Also, because the number of faculty agreeing to participate in the study self- selected, they may have increased their efforts to implement the 7 principles in their instruction resulting in some bias to the results. The authors encourage further research using the questionnaire including methods using a control group of faculty who are informed of evaluation using the instrument and those who are not.

\section{Summary}

In summation, the $21^{\text {st }}$ century classroom has evolved and matured. It is a far cry from the one-room schoolhouse of a century ago. Today, information is transmitted and shared with unprecedented speed. Today's student consumes quantities of information unknown and unheard of in the past. With the invention of online education, the classroom is transported from the confines of four walls to an unlimited universe. 
As educators, we are struggling to keep pace with the expansion of knowledge. We also struggle to measure the effectiveness of what we do, and the amount our students are learning. It is important, however, that we keep striving to measure our effectiveness and assess the level of our student's learning. One way to achieve this goal is through the use of the seven principles of effective teaching.

\section{References}

Allen, E. \& Seaman, J. (2013). Changing course: Ten years of tracking online education in the United States. Retrieved from: http://www.onlinelearningsurvey.com/reports/changingcourse.pdf

Baran, E., Correia, A., \& Thompson, A. (2013). Tracing successful online teaching in higher education: Voices of exemplary online teachers. Teacbers College Record, 115 (030306), pp. $1-41$.

Cable, J. \& Cheung, C. (2017). Eight principles of effective online teaching: A decade-long lessons learned in project management education. Project Management World Journal, Vol. VI (VII), pp. 1 - 16.

Chen, S.J. (2007). Instructional design strategies for intensive online courses: An objectivist- constructivist blended approach. Journal of Interactive Online Learning, 6(1), 72 - 86.

Chickering, A.W., \& Gamson, Z.F., (1987, March). Seven principles for good practice in undergraduate education. American Association for Higher Education Bulletin, 3-7.

Goldberg, D., Clement, D., \& Cotter, J. (2011). Development and alumni assessment of an interdisciplinary PhD program offered through a blended learning environment. Journal ofAllied Health, 40(3), 137-42. Retrieved fromhttp://search.proquest.com/docview/918112887? accountid=12553

Hadsell, L. (2005). Exploring values in the classroom: Three exercises for introductory economics. American Economist, 49(2), 51-59. Retrieved from http://search.proquest.com/docview/200725109? Accountid $=12553$

Hillman, K. (2005). The first year experience: The transition from secondary school to university and TAFE in Australia. LSAY Research Report 40.

Jonassen, D. (1999). Designing constructivist learning environments. In C. Reigeluth (Ed.) Instructional design theories and models: A new paradigm of instructional theory (Vol. 2, pp.215-239),New Jersey: Lawrence Erlbaum Associates.

Knowles, M. (1983). The Self-Directed Learner. Boston, MA.: Cambridge Press.

Lopez-Diaz, J., Ronquillo-Chavez, C., Madero-Villanueva, M., Robledo-Portillo,I., \& Dena-

Hernandez, J. (2018). Proposal and validation of a questionnaire of evaluation of the online teaching practice through the student opinion. The Online Journal of Distance Education and E-Learning, 6, (1), pp. 66 71.

Shieh, R. S., Gummer, E., \& Niess, M. (2008). The quality of a web-based course: Perspectives of the instructor and the students. TechTrends, 52(6), 61-68. Retrieved from http://search.proquest.com/docview/ 223115852 ? accountid $=12553$

U.S. Department of Education, National Center for Education Statistics. (2018). Digest of Education Statistics, 2016 (NCES 2017-094), Table 311.15.Retrieved from https://nces.ed.gov/programs/digest/ d16/tables/dt16_311.15.asp?current=yes

Verschelden, C. (2017). Bandwidth Recovery: Helping Students. Sterling, VA: Stylus Publishing, LLC

Weber, H., Hillmert, S., \&Rott, K. (2018) Can digital information literacy among undergraduates be improved? Evidence from an experimental study, Teaching in Higher Education

DOI: $10.1080 / 13562517.2018 .1449740$ 